\title{
Impact of Hybrid Instruction on Student Achievement in Post-Secondary Institutions: A Synthetic Review of the Literature
}

\author{
Mark A. Lamport | Randy J. Hill
}

Hybrid online instruction is a cross between traditional face-to-face classroom format and online-only instruction. The premise behind hybrid instruction is that it provides the benefits of personal interaction with the convenience and flexibility of online assignments and discussions. While there has been significant research on how students perceive this form of instruction, less exists on the impact of hybrid instruction on student achievement. The current data is varied, with a majority of studies showing increased achievement in the hybrid classroom compared to traditional classrooms, but similar achievement to online courses. Since hybrid formats are significantly varied in the percentage of time spent online, subject matters, student populations, etc., it can be difficult to compare methods solely focused on achievement. This article is a review of the literature that provides implications/recommendations for online teachers with empirically-based strategies and suggestions for the effective implementation of a hybrid course.

Hybrid online instruction is a cross between the traditional face-to-face classroom format and online-only instruction. The premise behind hybrid instruction is that it provides the benefits of personal interaction with the convenience and flexibility of online assignments and discussions. While there has been significant research on how students perceive this form of instruction, less exists on the impact of hybrid instruction on student achievement. The current data is varied, with a majority of studies showing increased achievement in the hybrid classroom compared to traditional classrooms, but similar achievement to online courses. Since hybrid formats are significantly varied in the percentage of time spent online, subject matters, student populations, etc., it can be difficult to compare methods solely focused on achievement.

The purpose of this paper is to compare the ad- vantages and disadvantages of hybrid instruction to online and traditional formats from the lens of professor, i.e., what to do and avoid in teaching a hybrid course, and ways of fostering student achievement.

\section{THE EMERGENCE OF THE HYBRID APPROACH TO ON- LINE LEARNING}

One relatively new method of instruction at the tertiary level that helps to minimize the disadvantages of a pure online environment is the hybrid, also known as blended, online learning. Hybrid instruction is an educational approach that combines traditional classroom instruction and online instruction. It was initially designed to ease students into the online transition and overcome anxieties related to the online learning environment (Oh \& Park, 2009). In a hybrid classroom, instructors utilize technologies, specifically online instructional 
components, to replace and augment portions of classroom instruction.

One of the biggest drawbacks is a lack of personal interactions and face-to-face

communication that exists in a traditional classroom. In one study, students enrolled in an online course noted that with the elimination of face-toface time with their teacher and peers, it was posited learning usually gained from assimilating information and interacting with other students and faculty was somehow seemed "lost" (Laine, 2003). Other hindrances identified include learner isolation (Brown, 1996), learner frustration, anxiety, and confusion (Hara \& Kling, 2000; Piccoli, Ahmad, \& Ives, 2001), high student attrition rates (Frankola, 2001; Laine, 2003; Ryan, 2001), and the need for greater student motivation, discipline, and time commitment (Golladay, Prybutok, \& Huff, 2000; Serwatka, 2003).

The entire concept behind hybrid instruction is to provide the benefits of online instruction (e.g., flexibility, ease of discussions) with those of the traditional classroom setting (e.g., face time, personal connections). As student outcomes should be top priority for any collegiate institution, the impact of hybrid instruction on student learning has a far reaching effect on whether or not colleges will begin offering or expanding their hybrid programs. The literature that focuses on the impact of hybrid instruction on student achievement generally falls into three subcategories: (1) studies that emphasize the amount of time designated to online activities; (2) studies that highlight the level of the students in the study population (undergraduate versus graduate); and (3) studies that compare hybrid instruction to complete online instruction. The impact of hybrid instruction on student achievement is therefore assessed in relation to these three variables.

Acknowledged advantages to hybrid instruction include student and instructor convenience, increased participation, flexibility, decrease in dropouts, and minimized costs (Garnham \& Kaleta, 2002; Young, 2002). Hybrid instruction is being used as a tool to effectively teach content material to students with varying learning disabilities and preferences. Potential challenges for hybrid instruction include training instructors to teach hybrid courses, allowing appropriate preparation time to modify their course, and training students in the new format. In addition, the success of hybrid courses depends on the perceptions of students and faculty towards this design. Since the emergence of online education, studies have been conducted on the impact of this form of education with regard to student achievement. The studies illustrate that students in an online setting performed equally as well (Davies \& Mendall, 1998) or better than (Schutte, 1997) face-to-face students (see http://www.nosignificantdifference.org/ for a complete review of the volumes of studies documenting these findings). Despite the vast number of studies comparing the online versus traditional classroom environments, few studies have looked at the impacts of hybrid instruction on student achievement.

\section{AMOUNT OF TIME DESIGNATED TO ONLINE VERSUS TRADITIONAL ACTIVITIES}

According to McFarlin (2008), the definition of hybrid is a course that combines "face-to-face classroom instruction with educational technologies often using online devices. A significant amount of learning in a hybrid course occurs online" (p. 86). In this definition, as is the case with most definitions of hybrid learning, there is no mention as to what percentage of the class should take place online versus in the classroom. Therefore, variations in time allocations could have a significant impact on student achievement in a hybrid course.

Some classes may require a minimal amount of online interaction for the students, but still fall in the category of a hybrid class. For example, Denoui \& Dodge (2006) examined a class that was completely in the traditional format and utilized Blackboard only to post contact information and assignments from the lecture, as well as for a means for communication. They tracked the students who utilized Blackboard, and found that students who utilized Blackboard generally did better in the class than those students who did not go online. McFarlin (2008), on the other hand, compared results between hybrid and traditional class formats, in which the hybrid format consisted of 1.5 hours/week in a traditional classroom and 1.5 hours/week online using a WebCT site. Martyn (2003) conducted all classes through an asynchronous online environment with the exceptions of the first and last class. The McFarlin and Martyn studies similarly demonstrated a positive correlation between hybrid instruction and student achievement, regardless of the proportions of time spent online versus in-class. 
Reynolds and Paulus (2009) compared two hybrid classrooms that varied in the requirements of time spent online. In one class, they reduced class time by $67 \%$ with the implementation of online video instruction, and in a second class, they reduced class time by $33 \%$ through an interactive online homework system. The results showed that the average increase in performance on three final assessments was $17 \%$ higher relative to assessment scores received by students taking traditional classes, regardless of how much time the students were required to spend online.

The studies mentioned above show a positive relationship between hybrid instruction and student achievement, regardless of the amount of time that students spent online. However, a number of other studies have indicated either no difference or a negative impact using similar time allocations in a hybrid class. In a similar method to Denoui and Dodge (2006), O'Toole and Absalom (2003) held a traditional class that met each week, but posted materials online through the university's intranet to supplement course meetings. Their findings show that attendance at the lectures, especially the final lecture, increased the overall final quiz grade. Students that relied solely on web material without the benefit of lecture attendance did not achieve the desired learning outcomes. Larson and Sung (2009) expanded upon the previous research to compare performance in an undergraduate course offered in an online, traditional, and hybrid format. In the hybrid class, students met face-to-face for eleven sessions, and in the online format, they met for five sessions. Results showed that there was no significant difference between the three methods of instruction in regards to student achievement.

There may be a range of variables and shortcomings that can potentially contribute to student success. Therefore it cannot be determined that the proportion of online versus traditional instruction had any impact on the results. For example, McFarlin (2008) used the same instructors for hybrid and traditional formats (while others used different instructors), and the classes were not run simultaneously which resulted in data collected on different students. Further, the type of media (Blackboard, WebCT, etc.) was not consistent among studies, adding another variable that could impact student success. Since studies have shown both positive and negative correlations between hybrid instruction and student achievement with various proportions of online vs. in-class instruction (McNaught, 2011).

\section{UNDERGRADUATE AND GRADUATE STUDIES IN HYBRID INSTRUCTION}

The amount and scope of undergraduate and graduate level coursework varies tremendously at most collegiate institutions. While the premise behind undergraduate work is to lay the foundation and cover topics more broadly, graduate work is more focused and usually involves more critical thinking and problem solving. While hybrid instruction can be favorable for students as it allows more flexibility, institutions must consider whether hybrid education offers differential learning gains as a function of the level (undergraduate or graduate) course.

Most of the published literature focuses on the undergraduate level. For example, Taradi, Taradi, Radic and Pokrajac (2005) examined the difference between a hybrid and traditional undergraduate course was and concluded that students in the hybrid courses received significantly higher scores on their final exam than traditional course students. Similarly, Melton, Graf, and Chopak-Foss (2009) examined student achievement and student satisfaction in a blended learning undergraduate course and compared these results to student achievement in a traditional course format. Results from this study show that there was no significant difference on the exam scores between and within groups, and there were two cases where the traditional group (blended versus traditional) outperformed the blended group. Overall, however, blended students had a higher average final grade.

Webb, Gill and Poe (2005) conducted a similar experiment to Taradi et al. (2005) but focused on the graduate level. The graduate students in the hybrid instruction showed an increase in knowledgelevel learning.

Boyle et al. (2003) studied the impact of hybrid learning on students by comparing a blended learning environment to a traditional learning environment. The passing rate for students in the hybrid courses increased by $12 \%$ to $23 \%$, relative to the pass rate for students taking traditional classes taught the previous year.

Although the Boyle study was the first study to compare formats of learning at different degree levels, it focused on student grades and did not take 
into consideration the factors required for a student to be successful in a self-regulatory environment, and how these have an impact on achievement. Kumrow (2005) examined the "five self-regulatory resource management strategies of time management, study environment, effort regulation, help seeking, and peer learning" (pg. 140) in a graduate nursing course taught in both the hybrid and traditional format. Students in the hybrid section had overall higher grades, and only the help seeking strategy was correlated with higher grades in both sections.

While many studies have shown positive correlations between hybrid instruction and student achievement at both the undergraduate and graduate level, other studies have either shown no impact or a negative correlation. Roscoe (2008) compared hybrid and traditional format 300-level undergraduate course on political parties and interest groups, with the hybrid class meeting five times face-toface in a 15-week semester, with the rest of the classes online. Both classes took the same tests quizzes, and assignments, and the hybrid students took their tests in one of the face-to-face sessions. Results from the assessments showed either form of instruction made no difference on the academic performance of students.

Riveria and Rice (2002) compared the results of a traditional, online, and hybrid graduate MIS course. Similar to the Denoui and Dodge (2006), the hybrid format consisted of traditional classroom time, with WebCT used only to deliver course materials and conduct discussions. The results of the exams showed that there was very little difference between all three modalities in student achievement. York (2008) expanded upon the study conducted by Riveria and Rice to implement the three modes on instruction into a graduate social work program, and also found that there was no difference among the three types in terms of knowledge gained.

\section{COMPARISON OF THE IMPACT OF HYBRID INSTRUCTION VERSUS ONLINE-ONLY INSTRUCTION}

All of the studies highlighted above compare the hybrid format to traditional face-to-face format. However, as previously mentioned, the number of online courses and programs are increasing at a rapid pace. There have been a number of studies that have compared traditional instruction to online instruction (Mirakian \& Hale, 2007; Johnson, Burnett, \&Rolling, 2002; Sue, 2005; see http://www.nosignificantdifference.org/ for a complete discussion of this comparative literature). However, very few studies compared hybrid instruction to complete online instruction to determine the impacts on student achievement.

Vengroff and Bourbeau (2006) compared achievement and participation of students taking an introductory comparative politics class in the traditional format, completely online, and through a hybrid class. The online and hybrid courses utilized the same materials as the traditional format for consistency, with the online and hybrid courses were implemented via an online platform. Student performance was measured with examinations, short research papers, and discussions (online and in class.) The results indicate exams between online and traditional formats were not significantly different, but that traditional students did considerably better on the research papers than online students. However, students in the hybrid classes did significantly better on both examinations and research papers. It should be noted that the hybrid classes consisted of honor students, which potentially skewed the results. However, the authors indicated that subsequent testing of hybrid classes with regular students yielded similar results. The traditional classes in this investigation, unlike traditional courses in other studies, had access to online materials to complement the lectures.

In a related study, Collopy and Arnold (2009) examined student learning in a hybrid and completely online format for teacher education students. Surveys were administered to determine how well the students learned the content and to determine their overall satisfactions with the course. The results illustrated that participants showed an increase in learning in both hybrid classes as compared to the completely online class. In addition, although the two hybrid classes varied in the amount of traditional class time, they reported similar levels of content learned, which emphasizes the importance of the classroom experience.

While the above studies indicate no difference in achievement between online and hybrid instruction, Detwiler (2008) discovered that an undergraduate cohort who took a GIS programming course in the hybrid format underperformed compared to the students who took the class completely online. This 
was one of the first studies that also examined student study habits between sections by having students keep a diary of the amount of time dedicated to the class. The author concluded, based on this qualitative data, that motivation and management skills may play a larger role in student success than the delivery mechanism of course content.

These two previous studies highlight the advantage of hybrid instruction over completely online courses in regards to student achievement. Unlike the comparison with traditional formats, however, a majority of the studies comparing hybrid to online courses resulted in either online instruction being more successful at increasing achievement, or there being no difference between the two (Blake, Wilson \& Pardo-Ballester, 2008; Larson \& Sung, 2009; Parker \& Nelson, 2009).

The studies highlighted in this section are extremely valuable as we increase the number of programs offered online, and the impacts that they will have on student achievement. However, it should be mentioned that a few of the studies used inadequate testing methods and did not keep variables consistent for accurate data. For example, Detwiler (2008) used different populations of students, with adult, working professionals participating in the online format and undergraduate students in residence taking the hybrid class. While the authors examined student diaries to obtain information on motivation, the classes should have been compared with the same population of students for more accurate data. In the study conducted by Parker \& Nelson (2009), student self-selected which format of the course they desired. This can potentially result in inaccurate data, as students who are already technologically literate will register for the online and hybrid class, which can give them an advantage to manipulating the media to learn the material.

In sum, the studies illustrated in this paper show the wide range in diversity between hybrid classes offered at different schools and in different programs. This includes the percentage of time spent online versus in class and whether the class is at the undergraduate or graduate level. In addition, accurate measurement of hybrid class achievement must be compared with both traditional and online instruction. The results of these studies indicate that both positive and negative achievement can be related to hybrid instruction regardless of the variables mentioned above, and therefore other variables, such as content, student age distributions, etc. must be examined to help determine this cause in variation.

\section{IMPLICATIONS FOR THE EFFECTIVE USE OF HYBRID INSTRUCTION}

While this article has focused on academic achievement, there are other benefits to hybrid instruction that colleges and universities must consider before implementing a hybrid program. These include student perceptions, faculty buy-in, and administrative costs, to name a few. Many of the studies on academic achievement highlighted in this paper also analyzed student perceptions in regards to hybrid courses (Boyle, et.al., 2003; Collopy \& Arnold, 2009; Larson \& Sung, 2009; Melton, Graff, \& Foss, 2009; Riveria \& Rice, 2002; Roscoe, 2008). In addition, several studies have been conducted that solely look at student perception and attitudes toward hybrid instruction (Buzzetto-More, 2008; Koohang \& Durante, 2003; Lin, 2008-2009; Marcketti \& Yurchisin, 2005; Senn, 2008; Yousif \& Lichty, 2005). The common themes among these studies were that students have positive perceptions of hybrid courses in regards to flexibility and instructor availability, while the negative perceptions primarily centered on problems with technology and not always having immediate help available. However, negative perceptions can result if the course material is not suited for the hybrid format. The study by Senn (2008) demonstrated that a course that requires a great deal of hands-on instruction and technological skills, such as educational technology in this case, was perceived as more difficult by the students in the hybrid format.

Furthermore, faculty inexperience and ineffectiveness can create negative attitudes toward hybrid format (Young, 2002). This is an important finding, demonstrating careful consideration must be taken in order to decide which classes should be transitioned to hybrid-based content and how faculty are trained to teach these courses.

While the studies in this article have compared academic achievement in hybrid versus traditional and online formats, there were many variables that were inconsistent amongst studies, which make it difficult for comparisons. Some of these variables include whether or not the class was taught by the same instructor, amount of time spent online versus face-to-face, course content, age of students 
involved, size of classes, or whether Blackboard or WebCT was used. To be effective, research needs to be consistent and minimize the impacts of these variables to truly focus on academic achievement. While authors can state whether or not the hybrid format has an improved academic achievement rate over traditional and/or online learning, it is difficult to conclude that this is a trend merely by comparing to other studies with so multiple variables. Research should examine hybrid versus traditional instruction across multiple colleges and universities and that exhibit the same demographics, course content, medium, etc. so that the results for academic achievement might be reliable.

Lastly, with the exception of Detwiler (2008), all of the studies sampled traditional college students, many of which have had significant exposure to technology. However, many online programs target working professionals who are considered non-traditional students. Research has shown that to effectively incorporate technology into an adult education setting, instructors must be cognizant of their learning styles, and various forms of instruction to cater to this unique population (HernandezGantes, 2009; Wang, 2009). Adult professionals who want to return to school may have a difficult time navigating an online course, and hybrid courses may work best for their schedules and learning methods. Therefore, although the studies mentioned show data-proven relationships between achievement and delivery, more needs to be researched on how hybrid instruction affects achievement on non-traditional college students at community and career colleges.

The studies highlighted in this article represent various results of hybrid training and student achievement:

\section{Author Biographies}

Mark A. Lamport has master's degrees from Wheaton and Princeton, and a Ph.D. in Curriculum and Instruction from Michigan State. After a career in the classroom of 25 years at Gordon (MA), Huntington (IN), and Grand Rapids Theological Seminary (MI), he now enjoys an online career with Grand Canyon (AZ), Liberty (VA), Colorado Christian, and Indiana Wesleyan. He is author of 125 academic articles, chapters, essays, and reviews in over thirty-five journals, books, and periodicals, and has published for 28 consecutive years. Lamport is in the final stretch of a four-year adventure teaching at theological schools in Amsterdam, Belfast, Brussels, London, and Lisbon. He is the father of four married young adults and grandfather to five. He enjoys Anthony Hopkins movies; buying clocks and oriental carpets; long-distance running; the Chicago Cubs; his wife's cooking; international travel; and the summer Olympics.

Randy Hill received a Bachelor of Science (Natural Resources) and a Master of Arts (Teaching) from the University of Maine, a Master of Science (Marine Science) from the University of South Florida, an Educational Specialist (Educational Leadership) from Liberty University, and is currently pursuing a Doctorate in Education (Educational Leadership) from Liberty University. Hill is the Dean of Education \& Human Service at Baker College in Cadillac, Michigan. Previous positions have included being a middle school science teacher and an educational director for several environmental education nonprofit institutions.
- The majority show improved achievement for students in hybrid classes relative to those taking traditional classes.

- Generally, there is no significant difference between hybrid and online classes suggesting that classroom interaction may not be necessary to achieve desired outcomes.

-Achievement is connected towards more than just the method of content delivery; student motivation, experiences, and time management abilities are also factors in how well students perform in a particular course, despite how it is delivered. 


\section{References}

Allen, I. E., \& Seaman, J. (2008). Staying the course: Online education in the United States, 2008 (2008 Sloan Survey of Online Learning).

Retrieved from the Sloan Consortium website: http://sloanconsortium.org/

Beeghly, D.G. (2005). It's about time: Using electronic literature discussion groups with adult learners. Journal of Adolescent \& Adult Literacy, 49(1), 12-21.

Blake, R., Wilson, N., Cetto, M., \& PardoBallester, C. (2008). Measuring oral proficiency in distance, face-to-face, and blended classrooms. Language Learning \& Technology, 12(3), 114-127. Retrieved from http://llt.msu.edu/

Boyle, T., Bradley, C., Chalk, P., Jones, R., \& Pickard, P. (2003). Using blended learning to improve student success rates in learning to program. Journal of Educational Media, 28(2/3), 165-178. doi: 10.1080/1358165032000153160.

Brown, K.L. (2003). From teacher-centered to learner-centered curriculum: Improving learning in diverse classrooms. Education, 124(1), 49-54.

Brown, K.M. (1996). The role of internal and external factors in the discontinuation of off campus students. Distance Education, 17(1), 44-71.

Buzzetto-More, N.A. (2008). Student perceptions of various e-learning components. Interdisciplinary Journal of Knowledge and Learning Objects, 4, 113-135.

Bybee, R.W., \& Starkweather, K.N. (2006). The twenty-first century workforce: A contemporary challenge for technology education. Technology Teacher, 65(8), 27-32.

Cao, Q., Griffin, T.E., \& Bai, X. (2009). The importance of synchronous interaction for student satisfaction with course web sites. Journal of Information Systems Education, 20(3), 331-338.

Collopy, R.M.B., \& Arnold, J.M. (2009). To blend or not to blend: Online and blended learning environments in undergraduate teacher education. Issues in Teacher Education, 18(2), 85-101.

Davies, R.S., \& Mendenhall, R. (1998). Evaluation comparison of online and classroom instruction for HEPE 129--Fitness and lifestyle management course. Retrieved from ERIC database. (ED427752)
D'Orsie, S. M., \& Day, K. (2006). Ten tips for teaching a web course. Tech Directions, 65(7), 18-20.

DeNeui, D.L., \& Dodge, T.L. (2006). Asynchronous learning networks and student outcomes: The utility of online learning components in hybrid courses. Journal of Instructional Psychology, 33(4), 256-259.

Detwiler, J.E. (2008). Comparing student performance in online and blended sections of a GIS programming class. Transactions in GIS, 12(1), 131-144.

El Mansour, B., \& Mupinga, D. M. (2007). Students positive and negative experiences in hybrid and online classes. College Student Journal, 41(1), 242-248. doi:10.1111/j.1467-9671.2008.01089.x

Franzoni, A.L., \& Assar, S. (2009). Student learning styles adaptation method based on teaching strategies and electronic media. Journal of Educational Technology \& Society, 12(4), 15-29.

Garnham, C., \& Kaleta, R. (2002). Introduction to hybrid courses. Teaching with Technology Today, 8(6). Retrieved from http://www. wisconsin.edu/ttt/index.htm

Greenberg, K., Lester, J.N., Evans, K., Williams, M., Hacker, C., \& Halic, O. (2008). Student learning with performance-based, in-class and learner-centered, online exams. International Journal of Teaching and Learning in Higher Education, 20(3), 383-393.

Greer, A., \& Mott, V. (2009). Learner-centered teaching and the use of technology. International Journal of Web-Based Learning and Teaching Technologies, 4(4) 1-16. doi: 10.4018/ jwbltt.200909150

Hernandez-Gantes, V.M. (2009). Teaching adult learners in online career and technical education. International Journal of Web-Based Learning \& Teaching Technologies, 4(4), 32-49. doi: 10.4018/jwbltt.2009091502

Jackson, M.J., \& Helms, M.M. (2008). Student perceptions of hybrid courses: Measuring and interpreting quality. Journal of Education for Business, 84(1), 7-12.

Johnson, D., Burnett, M., \& Rolling, P. (2002). Comparison of Internet and traditional classroom instruction in a consumer economics course. Journal of Family and Consumer Sciences, 20(2), 20-28. 
Kia, M. M., Aliapour, A., \& Ghaderi, E. (2009). Study of learning styles and their roles in the academic achievement of the students of Payame Noor University (PNU). Turkish Online Journal of Distance Education, 10 (2), 24-37.

Kirtman, L. (2009). Online versus in-class courses: An examination of differences in learning outcomes. Issues in Teacher Education, 18(2), 103-116.

Koohang, A., \& Durante, A. (2003). Learners' perceptions toward the web-based distance learning activities/assignments portion of an undergraduate hybrid instruction model. Journal of Information Technology Education, 2, 105-113. Retrieved from http://jite.org/ index.html

Kumrow, D.E. (2007). Evidence-based strategies of graduate students to achieve success in a hybrid web-based course. Journal of Nursing Education, 46(3), 140-145.

Laine, L. (2003). Is e-learning e-ffective for IT training? T+D, 57(6), 55-60.

Larson, D.K., \& Sung, C.H. (2009). Comparing student performance: Online versus blended versus face-to-face. Journal of Asynchronous Learning Networks, 13(1), 31-42.

Lepper, M.R., Corpus, J.H., \& lyengar, S.S. (2005). Intrinsic \& extrinsic motivational orientations in the classroom: Age differences and academic correlates. Journal of Educational Psychology, 97(2), 184-196. doi:10.1037/0022-0663.97.2.184

Lin, Q. (2008/2009). Student views of hybrid learning: A one-year exploratory study. Journal of Computing in Teacher Education, 25(2), 57-66.

Marcketti, S.B., \& Yurchisin, J. (2005). Student perceptions of a hybrid course. Academic Exchange Quarterly, 317-320.

Martyn, M. (2003). The hybrid online model: Good practice. Educause Quarterly, 1, 18-23.

McFarlin, B.K. (2008). Hybrid lecture-online format increases student grades in an undergraduate exercise physiology course at a large urban university. Advances in Physiological Education, 32(1), 86-91. doi: 10.1152/advan.00066.2007

McGlynn, A. (2008). Millennials in college: How do we motivate them? Education Digest, 73(6), 19-22.
McNaught, C. (2011). The best of both worlds: Effective hybrid learning designs in higher education in Hong Kong. In Kwan, R., Fong, L., \& Lam, J. (Eds.), Hybrid learning 4th international conference, ICHL 2011, Hong Kong China, August 10-12, 2011 proceedings (pp. 1-9). New York: Springer-Verlag.

Melton, B., Graf, H., \& Chopak-Foss, J. (2009). Achievement and satisfaction in blended learning versus traditional general health course designs. International Journal for the Scholarship of Teaching and Learning, 3(1), 1-13.

Mirakian, E.A., \& Hale, L.S. (2007). A comparison of online instruction vs. traditional classroom instruction in an undergraduate pharmacology course. Proceedings of the 3rd Annual GRASP Symposium, Wichita State University, 95-96. Retrieved from http:// soar.wichita.edu/dspace/bitstream/10057/721/1/96.pdf

Moe, T., Cuban, L., \& Chubb, J. (2009) Virtual schools: Will education technology change the nature of learning? Education Next, 9(1).

Retrieved from http://educationnext.org/virtual-schools/

Moon, T.R., Brighton, C.M., Callahan, C.M., \& Robinson, A. (2005). Development of authentic assessments for the middle school classroom. Journal of Secondary Gifted Education, 16(2/3), 119-133.

Nagel, D. (2009, October 28). Most college students to take classes online by 2014. Campus Technology. Retrieved from http:// campustechnology.com/Home.aspx

National Association of Secondary School Principals (1979). Student learning styles: Diagnosing and prescribing programs. Reston, VA: Author.

O'Toole, J.M., \& Absalom, D.J. (2003). The impact of blended learning on student outcomes: Is there room on the horse for two? Journal of Educational Media, 28(2/3), 178-190. doi: 10.1080/1358165032000165680

Oh, E., \& Park, S. (2009). How are universities involved in blended instruction? Educational Technology \& Society, 12(3), 327-342.

Orton-Johnson, K. (2009). 'I've stuck to the path I'm afraid': Exploring student non-use of blended learning. British Journal of Educational Technology, 40(5), 837-847. doi: 10.1111/j.14678535.2008.00860.x 
Park, J.H., \& Choi, H. J. (2009). Factors influencing adult learners' decision to drop out or persist in online learning. Journal of Educational Technology \& Society, 12 (4), 207-217.

Parker, T., \& Nelson, P.S. (2009). A comparison of the effectiveness of face to face, online and hybrid formats in a principles of macroeconomics course. Retrieved from http://papers.ssrn.com/ sol3/papers.cfm?abstract_id $=1412388$

Parkinson, D., Greene, W., Kim, Y., \& Marioni, J. (2003). Emerging themes of student satisfaction in traditional courses and blended distance courses. TechTrends, 47(4), 22-28.

Phelps, P.H. (1990). Overcoming the puzzlement of passivity. College Teaching, 38(1), 20.

Piccoli, G., Ahmad, R. \& Ives, B. (2001). Web-based virtual learning environments: A research framework and a preliminary assessment of effectiveness in basic IT skills training. MIS Quarterly, 25(4), 401-426.

Prensky, M. (2001). Digital natives, digital immigrants. On the Horizon, 9(5), 1-6. Retrieved from http://www.emeraldinsight.com/ journals.htm?issn=1074-8121

Prensky, M. (2008). Let's be "digital multipliers:" Eliminating the digital divide is something educators can do. Educational Technology, (January/February), 1-9. Retrieved from http://www.marcprensky. com/writing/Prensky-Lets_Be_Digital_Multipliers-ET-01-09.pdf

Reynolds, M. \& Paulus, D. (2009, September). The best of both worlds: Hybrid learning. Paper presented at the 2009 Midwest Section Conference of the American Society for Engineering Education, University of Nebraska-Lincoln, NE.

Rivera, J.C., McAlister, M. K., \& Rice, M.L. (2002). A comparison of student outcomes and satisfaction between traditional \& web based course offerings. Online Journal of Distance Learning Administration, 5(3), 1-12. Retrieved from http://www.westga. edu/ distance/ojdla/

Roscoe, D. D. (2008, August). Comparing student outcomes in blended and face-to-face courses. Paper presented at the annual meeting of APSA 2008 Annual Meeting, Hynes Convention

Center, Boston. Retrieved from http://www.allacademic.com/meta/ p278414_index.html

Ryan, S. (2001). Is online learning right for you? American Agent \& Broker, 73(6), 54-58.
Saeed, N., Yang, Y., \& Sinnappan, S. (2009). Emerging web technologies in higher education: A case of incorporating blogs, podcasts, and social bookmarks in a web programming course based on students' learning styles and technology preferences. Educational Technology \& Society, 12(4), 98-109.

Saulnier, B.M., Landry, J.P., Longenecker, H.E., \& Wagner, T.A. (2008). From teaching to learning: Learner-centered teaching and assessment in information systems education. Journal of Information Systems Education, 19(2), 169-174.

Schutte, J. (1997). Virtual teaching in higher education: The new intellectual superhighway or just another traffic jam? Retrieved from http://ddi. cs.uni-potsdam.de/HyFISCH/Teleteaching/VirtualTeachingSchutte.htm

Senn, G.J. (2008). Comparison of face-to-face and hybrid delivery of a course that requires technology skills development. Journal of Information Technology Education, 7, 267-283. Retrieved from http://informingscience.org/jite/documents/Vol7/JITEv7p267283Senn309.pdf

Serwatka, J. (2003). Assessment in on-line CIS courses. Journal of Computer Information Systems, 43(3),16-20.

Smart, K.L. \& Cappel, J.J. (2006). Students' perceptions of online learning: A comparative study. Journal of Information Technology Education, 5, 201-219.

Steinman, D. (2007). Educational experiences and the online student. Tech Trends, 51(5), 46-52. doi: 10.1007/s11528-007-0069-x

Sue, V.M. (2005). Comparing online and traditional classes.Academic Exchange Quarterly, (22).

Stewart, V. (2005). A world transformed: How other countries are preparing students for the interconnected world of the 21st century. Phi Delta Kappan, 87(3), 229-232.

Taradi, S.K., Taradi, M., Radic, K., \& Pokrajac, N. (2005). Blending problem-based learning with web technology positively impacts student learning outcomes in acid-base physiology. Advances in Physiological Education, 29(1), 35-39. doi: 10.1152/advan.00026. 2004 
Tomlinson, C. A. (2000). Differentiation of instruction in the elementary grades. Retrieved from ERIC database. (ED443572)

Vengroff, R. \& Bourbeau, J. (2006, February). In-class vs. on-line and hybrid class Participation and outcomes: Teaching the introduction to comparative politics class. Paper presented at the annual meeting of the APSA Teaching and Learning Conference, Renaissance Hotel, Washington, DC. Retrieved from http://www. allacademic.com/meta/p101324_index.html

Vondracek, M. (2009). Teaching with multiple methods in mind. The Science Teacher,76(3), 38-41.

Wang, V.C.X. (2009). Effective teaching with technology in adult education. International Journal of Web-Based Learning \& Teaching Technologies, 4(4), 17-31. doi: 10.4018/jwbltt.2009091502

Webb, H.W., Gill, G., \& Poe, G. (2005). Teaching with a case method online: Pure versus hybrid approaches. Decision Sciences Journal of Innovative Education, 3(2), 223-250. doi:10.1111/j.1540 4609.2005.00068.x

Weimer, M. (2002). Learner-centered teaching: Five key changes to practice. San Francisco: Jossey-Bass.

York, R.O. (2008). Comparing three modes of instruction in a graduate social work program. Journal of Social Work Education, 44(2), 157-172.

Young, J. (2002, March 22). "Hybrid" teaching seeks to end the divide between traditional and online instruction. The Chronicle of Higher Education,48(28), A33-34.

Yousif, M., \& Lichty, M. (2005). Student perceptions of an on-line hybrid fcs capstone course. College and University Media Review, 22(5), 20-33. 